\title{
Toward a Conceptual History of Nafir Suriyya
}

JENS HANSSEN

Both words of the title of al-Bustani's pamphlets require investigation, as well as his definition of them as wataniyyat: What did he mean by nafir and what would have been its connotations? And what did Suriyya mean to al-Bustani and his generation? Was it a description of a real territory or a potentiality? al-Nafir and Suriyya are terms that go back to antiquity, but neither had much traction outside liturgical literature until contact with Protestant missionaries gave them new political valence.

al-Nafir means "clarion" or "trumpet," which was perhaps so self-evident that al-Bustani did not explain the term in his pamphlets. ${ }^{I}$ But in Mubit al-Mubit, he dedicated almost an entire page to the different declinations and meanings of the root $n-f-r$ (from the "bolting of a mare," to "raising of troops," "the fugitive," "estrangement," and "mutual aversion"), before defining al-nafir itself: "someone enlisted in a group or cause," and "al-nafir al-'am means mass mobilization to combat the enemy." The Protestant convert al-Bustani also lists yawm al-nafir (Judgment Day) ${ }^{2}$ and informs the reader that al-nafir is also a trumpet or fanfare $(a l-b u q)^{3}$ containing associations with Israfil, 


\section{6 / Chapter 4}

the archangel of death alluded to in the Bible and the Quran. ${ }^{4}$ Then he mentions Nafir Suriyya itself as a set of "meditations on the events of 1860 published in eleven issues that we called wataniyyat." Like many historians before us, we translate the term as "clarion" in order to capture both the apocalyptic mood of the text and the author's passionate call for social concord and overcoming adversity?

At first sight, the term Suriyya is less complex. After all, alBustani defined the territory as Barr al-Sham and Arabistan, two Ottoman terms for what later Syrian nationalists considered Greater Syria. But al-Bustani did not give clear boundaries for this land except to lament in issue 5 that "Syria lies between two countries [Egypt and Turkey] that have often pulled it in different directions." So why did he replace Barr, or Bilad alSham, the common referent for Ottoman Syria, with the ancient

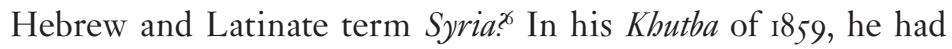
delineated the essence of and threats to Arab culture, but he made no reference to Syria. Nafir Suriyya was the first instance where al-Bustani annunciated "ancient Syria" as a parameter of identity, as a benchmark for contemporary Syrians and a source of social unity?

The political semantics first began to shift from Bilad-or Barr-al-Sham and Arabistan to Syria during the Egyptian occupation from i83 I to I840. Nafir Suriyya's paradigmatic adoption of "Suriyya" very likely stems from its author's contact with American missionaries, particularly Eli Smith. In I833, the same year Nasif al-Yaziji wrote his Historical Treatise on the Conditions of Mount Lebanon in Its Feudal Age, Smith had defined Syria as the "general name for the country that lies along the whole breadth of the Eastern end of the Mediterranean Sea, extending inland to the deserts of Arabia, and having the territories of Egypt on the south, and the river Euphrates with the mountains of Cilicia on 
the north."9 From the first literary society al-Bustani cofounded with Eli Smith in 1847 to Daniel Bliss's Syrian Protestant College in I866, the Americans propagated a Syrianist imagination that was conspicuously at odds with Muslim, Ottoman, and Lebanist geographical imaginations.

Nafir Suriyya contained many ideas about Syria that were already expressed in Beirut's first privately run newspaper, Hadiqat al-Akbbar. Its editor-in-chief, Khalil Khuri (I836-1907), was al-Bustani's neighbor, a noted fiction writer, and an amateur historian..$^{\circ}$ His book Kharabat Suriyya, the Ruins of Syria (I86I) was the first in Arabic to use Syria in the title of a major Nabda publication and drew on archaeological texts of the early missionaries and adopted their mournfulness about current day Syria: "Where are the temples of Baalbak and Jerusalem? Where is the royal purple of Tyre? Where are the workshops of Saida and the academies of Beirut? ... All is long gone." had set out to reclaim the Holy Land but instead of returning to the roots of Christianity, they ended up in Beirut, where contact with its inhabitants, particularly the literary figures, and the civil war of 1860 forced them to adjust their preconceived ideas. ${ }^{12}$ One of Nafir Suriyya's remarkable features was how it turned the experience of violence and loss—without diminishing it - into a calling for hope that even American missionaries came around to adopting. It is in this sense of forging a Syrian community of suffering that the idea of patriotism with all its contradictions"it repeats the event it wishes only to have described"-was born. ${ }^{13}$

Subsequent local historians of the "Syrian nation," starting with Elias Matar (I874), Jurji Yanni (I88I), and Yusuf Dibs (1893-1905), elided "Syria's" "baptism of fire" of 1860 and telescoped deep into the past. ${ }^{14}$ Like Khuri and al-Bustani, they did so relying largely on European literature. ${ }^{15}$ What changed was 


\section{8 / Chapter 4}

the emergence of geographical determinism. It had its origins in French cartography and archaeology, particularly Elisée Reclus's influential Nouvelle géographie universelle (I884) and Victor Bérad's Les Phéniciens et l'Odysée (1902), and was popularized in Beirut by the Jesuit geographer and historian Henri Lammens (I862-I937). The geographical determinism of these geographers and their students at the Université de St. Joseph was Islamophobic and anti-Ottoman. It conjured up Syria as a distinctly Christian and non-Arab territorial entity in which "Lebanon is for Syria what the Nile River is for Egypt." ${ }^{\prime 6}$ These early expressions of Syrianism and Lebanism had much in common with each other but little with those of the Bustanis. These exclusivist ideas were an anathema to the pre-Mandate Nabda.

Only when the Ottoman decentralization movement and Arab nationalism challenged both Phoenicianism and the Syrian antiquity narrative after the Young Turk Revolution of I908 did Syrian and Lebanese nationalisms start to move apart and compete with each other. ${ }^{17}$ Syrian nationalists challenged the old narrative that Syrians were Christian. They insisted that Syrians were Arabs and began to claim that Damascus was "the beating heart of Arabism." Since the political turbulence following the end of Ottoman rule, most articulations and explorations of Arab nationalisms have focused on their transformation from "birth" to maturation to aberration, apogee, or "death." This diachronic scheme charts the transition from territory-based patriotism to ethnocentric nationalism, i.e., from nineteenth-century wataniyya to twentieth-century qawmiyya. If al-qawmiyya came to challenge the colonial division of the Arab nation in the twentieth century, it also criticized the alleged parochialism of wataniyya formations. ${ }^{18}$ These later conceptual battles were not al-Bustani's problem space. His idea of 
Syria was unencumbered by colonial and nationalist occupation with the geographic form of the nation, border drawing, and demographic exclusions. Rather, he was preoccupied with the constitution of a transcendent harmonious community.

al-Watan was the central concept throughout Nafir Suriyya. But in Clarion 5, a new sociological concept appeared for the first time, al-jinsiyya: the new "the source of attachment . . is kinship (al-jinsiyya)." In this passage, al-Bustani laments the way in which the resurgence of prejudice (al-gharadh) against other groups has shifted from an interfactional designation of us versus them to one based on hitherto "sacred names, ... like Druze and Christian, then Muslim and Christian." al-Finsiyya has come to mean nationality and the normative source of attachment to the independent nation-state. al-Bustani's al-finan, Ahmad Faris al-Shidyaq's al-Fawa'ib, and other journals that cropped up from the i87os onward first willed the semantic shift from kinship to nationality. ${ }^{19}$ They understood that language can formulate new political communities.

al-finsiyya, an abstract noun derived from al-jins, occupies center stage in Nafir Suriyya starting from the November 1860 Clarion, notably when the discussion shifts from Syria to Arab culture: "we advise you to avoid this natural inclination to condemn an entire race [al-jins] and to attack it because of the failings of some of its members." al-Fins, too, has undergone significant shifts in meaning since al-Bustani penned Nafir Suriyya. ${ }^{20}$ The abstract noun of janasa (to make alike, to classify, to assimilate), al-jins has been around since early Arabic literature. But in the context of racial stereotyping, it was of recent coinage, and al-Bustani may have been alerted by American missionaries' discourse on the Arabs. For example, Eli Smith invoked al-jins al-'arabi in a lecture to one of al-Bustani's new cultural societies in 1849 . The fact 
that al-Bustani speaks of a "natural inclination" suggests that jins may not have referred to a new concept imported by foreigners but was likely a new term for an existing concept.

Nahdawis and missionaries alike believed that people could escape racial stereotypes. The particularly brutal history of racism in the Americas along with insights of the twentieth century spawned anticolonial theorists and critical race theorists. al-Bustani, by contrast, did not have the vocabulary to challenge racism itself. So, instead of challenging the epistemic Eurocentrism of his times, he advocated a program to improve the destiny of Arab society and individuals and adapt to new conditions. The concepts central to this undertaking were al-adab and al-tamaddun.

Today's Arabic readers know adab as "literature." ${ }^{21}$ In classical Arabic al-adab's semantic range included sophisticated habits, good behavior, and the ability to fulfill one's role in society, a sense it retains today negatively in the phrase qalil al-adab (uncouth) and positively in mu'addab (polite). In al-Bustani's times, al-adab was located somewhere between morals (alakblaq) and education (al-talim). The former had ethical resonances in Islamic political philosophy while the latter denoted the Nabda's mantra of public education, expressed by al-Bustani in his lecture "On the Education of Women," written in I849. Neither alternative term appears in Nafir Suriyya - al-Bustani used akblaq only once, in his follow-up article "Patriotism is an Element of Faith" in al-finan, published in 1870 . In his lecture on $\bar{a} d \bar{a} b$ al-Arab, published in 1859 , al-Bustani gestured toward the academic concept of the "Arab humanities" in the plural of $a l$-adab- "the subject is ādāb al-Arab, or the sciences (al-'ulum), arts (al-funun), or knowledge (al-maiarif) of the Arabs." ${ }^{\prime 2}$ But most translations, correctly, render the title as "the culture of the Arabs." ${ }^{23}$ In Nafir Suriyya the meaning of al-adab is some- 
what different from that in his lecture a year before; the emphasis is more on lessons learned from the mistakes of belligerent human behavior and collective "unbridled passions." In this context, moral and morals seem to have a more apt connotation in our translation of al-adab/adabi than the semantics of culture and cultural. $^{24}$

al-Bustani dedicated issue in of Nafir Suriyya to the desirability and acquirability of civilization. ${ }^{25}$ In this final patriotic pamphlet, al-Bustani sets out to differentiate the population, between those who merit the homeland and the reforms he advocated, on the one hand, and those who disqualify themselves by their unworthy deeds, on the other. Drawing on Ibn Khaldun, he claims that al-tamaddun (civilization) is derived from the word madina (city) and "opposed to the lifestyle of the Bedouins who lack civilization." "The natural state into which man is born is barrenness" but with innovation, hard work, and diligence one can achieve the highest standards of civilization. In many ways, al-Bustani shared Matthew Arnold's conservative, if not elitist, definition of culture as "the study of harmonious human perfection." ${ }^{26}$

Adopting the racist taxonomy of Western missionaries, alBustani holds that half way between the "cannibals of distant Africa" and the "dignitaries of Paris and England," the fault line between barbarity and civilization passes right through Syria between "the Arab inhabitants of the desert and the inhabitants of Beirut." But "genuine civilization is that state of social organization which suits the development of all forces of the human race, individually and collectively." If everybody was to be brought into the national fold and given the chance at civilization, the prospective nation would be a distinctly urban utopia. Stereotypical Arab Bedouins, however, remain a constant menace and anxiety-inducing threats of civilizational relapse. 


\section{$52 /$ Chapter 4}

Culture-talk and clash-of-civilization narratives have haunted the West and the Middle East since civilization first entered the Orientalist paradigm in the early nineteenth century. ${ }^{27}$ But, as Peter Hill reminds us, the Arab discourse on civilization changed even during al-Bustani's lifetime. In fact, there was a significant shift between Khalil Khuri's use of tamaddun in the late I85os and the invocations in Nafir Suriyya that reflects an intellectual crisis of confidence in al-Bustani, precipitated by the war of 1860. While the owner of Hadiqat al-Akbbar expressed optimism for the "new age" and autogenetic attainability of the highest stages of "civilization," the author of the "Lecture on the Culture of the Arabs" and Nafir Suriyya was not so sanguine about the prospects of cultural refinement alone and insisted that in the current global competitiveness, no culture is an island. By the I87os the meaning of being a civilized compatriot had consolidated around the mastery of synthesis of essential Arab qualities and contingent European accomplishments. ${ }^{28}$ 